\title{
The Roots of Israel-Palestine Conflict: A Political Culture Analysis
}

\author{
IImi Dwiastuti ${ }^{1}$ \\ International Relations Study Programme, Faculty of Humanities, President \\ University ${ }^{1}$ \\ ilmi.dwiastuti@president.ac.id ${ }^{1}$
}

\begin{abstract}
ABSTRAK
Penyebab konflik berkepanjangan antara Israel dan Palestina telah menjadi perdebatan sejak konflik ini bermula di awal abad 20. Berbagai penelitian telah menjelaskan faktor-faktor penyebab konflik melalu berbagai instrument dan teori. Tulisan ini ingin menganalisis penyebab konflik dari sisi budaya politik masing-masing bangsa dengan menggunakan teori Budaya Politik dari Gabriel Almond dan Sydney Verba. Analisis akan dilihat dari tiga komponen. Pertama, sistem budaya, proses budaya, dan kebijakan budaya Israel dan Palestina. Kedua, orientasi perilaku masingmasing bangsa terhadap sistem politik. Ketiga, respon dan perilaku Israel dan Palestina terhadap kebijakan luar negeri dan dalam negeri di dalam sistem politik. Tulisan ini menilai bahwa penyebab konflik terjadi akibat adanya benturan kepentingan dan kepercayaan dari kedua pihak yang melekat pada budaya politik masing-masing. Israel meyakini bahwa tanah yang mulanya ditempati bangsa Palestina merupakan hak mereka yang diamanahkan kepercayaan mereka. Tidak hanya itu, misi pergerakan Zionisme juga menjadi salah satu sumber konflik berkepanjangan ini. Kemudian, nilai-nilai ini berbenturan dengan budaya politik bangsa Palestina sebagai bagian dari bangsa Arab. Tulisan ini menyimpulkan bahwa penggunaan teori budaya politik cukup untuk menjelaskan akar permasalahan IsraelPalestina selama ini dalam ranah identitas dan perilaku kedua bangsa berdasarkan kepentingan politiknya masing-masing. Namun, penggunaan teori ini kurang dapat menjabarkan dengan detail sejauh mana budaya politik bangsa Palestina menjadi akar dari konflik abadi ini.
\end{abstract}

Kata Kunci: Israel-Palestine, Konflik, Budaya Politik, Orientasi Politik, Nilai 


\section{ABSTRACT}

The cause of the prolonged conflict between Israel and Palestine has been debated since the conflict began in the early 20th century. Various studies have explained the causes of conflict through instruments and theories. This paper analyzes the conflict through the lens of political culture theory of Gabriel Almond and Sydney Verba. The analysis will be carried out three components. First, the cultural systems, cultural processes, and cultural policies of Israel and Palestine. Second, the behavior of each nation towards the political system. Third, the response and behavior of Israel and Palestine to foreign and domestic policies in the political system. This paper considers that the causes of conflict occur due to the conflict of interests and beliefs of the parties inherent in their respective political cultures. Israel believes that the land originally occupied by the Palestinians is their right to which their belief is entrusted. Not only that, the mission of the Zionism movement is also one of the sources of this prolonged conflict. Then, these values clashed with the political culture of the Palestinian people as part of the Arab nation. This paper concludes that political culture is sufficient to explain the roots of the Israeli-Palestinian problems so far in the realm of identity and the behavior of their respective political interests. However, it is unable to explain the extent to which the political culture of the Palestinian people is the root of this eternal conflict.

Keywords: Israel-Palestine, Conflict, Political Culture, Political Orientation, Value

\section{Introduction}

The causes of the Israel-Palestine conflict have been debated since the beginning of the 20th century (Beinin and Hajjar, 2014). Neal (1995), Harms and Ferry (2005, Spangler (2015), Oord (2008) have been trying to analyze the roots of conflict, as they questioned why it happened in the very first stage Jews people encountered Arab Palestine. Most of their analysis use historical sources and events analysis of the conflict, and through theological perspective to figure out the origins of the conflict.

Culture has been one of the most prominent variables in explaining the causes of conflict since the characteristics, norms, beliefs, behavior, and interest of each nation dominate the dynamic of conflict. However, few analyze it within the political culture theory. This presents an interesting gap for research using a political culture approach. As Andrew Bove (2002) asserts, political culture appears as a new context in political analysis that was not just a 'vague backdrop' but it was measurable and 
could incorporate into the causal analysis. It means political culture "thought to fill a major gap in explanatory models in political science based on the rational interest of the political actor". Political culture is useful to identify the roots of the conflict as norms, beliefs, values dominated the vision of the nation and drive the nation into, mostly, clash with other nation's culture. It helps understand Israeli and Palestinian political action before and after the establishment of the State of Israel. Thus, a political culture approach can help the leaders, international community, and the United Nations to seek another peace resolution.

This paper will assess the roots of the Israel-Palestine conflict within political culture approach of both Israeli and Palestinian nations. This paper is divided into five sections. The first section presents the concept and usage of political culture as a tool for analysis. The second section elaborates Israel and Palestine's political culture. The third section analyses the contribution of Israel and Palestine's political culture to general ideas of causes of their conflict. Subsequently, the fourth section of this paper examines how political culture aids understanding the causes by bringing both points of view into analysis and to what extent political culture variable has relevancy in assessing the causes of Israel-Palestine conflict. The sixth section concludes that the political culture variable is sufficient to understand the underlying reasons of the Jewish and Palestinian behavior in the conflict.

\section{Literature Review}

\subsection{An analysis of the roots of the Israel-Palestine issue}

Neal (1995) traces the roots of the Israel-Palestine issue through historical analysis of the events of the conflict, showing that national consciousness is one of the roots of the conflict without mentioning it as part of political culture. She highlights the emergence of the Zionist movement under Herzl's initiative as the initial clash between the two nations. This action also triggers the rise of nationalism of Palestinian Arabs during that time. She also emphasized that cultural misunderstanding become their clashed long before the Balfour declaration in 1917 . She believes the clashed happened in 1882 through the historical event of the First Aliya (wave of migration) of Zionist Jews into Palestine (Neal, p.1). Similarly, Oord (2008) used written historical sources in explaining the origins of the Palestine-Israel conflict. He analyses the conflict from a Western perspective, through religious and political narratives. He argues that the idea of the "white man's burden" encouraged Western countries to have responsibility for Palestinian amid the collapse of the Ottoman Empire which contributes to the origins of the Israeli-Palestinian conflict.

Harms and Ferry (2005) used a theological perspective to understand the Jews' behavior and actions after Jewish communities were expelled from Europe and the Zionist effort in claiming the Holy Land after they were expelled from Europe. To 
determine the cause of the conflict from Palestine's side they trace the historical event back to the World War I era. The rise of nationalism in Europe contributed to the emergence of collective awareness of Palestine Arab communities towards their territory. Thus, it impacts the development of a Palestinian identity who started to think about the land.

Spangler (2015) identified the causes of conflict during the pre-state period in the history of Zionism. An anti-Semitism and Enlightenment period helped nurture Zionism, as they gradually yearned and sought for a land where they could avoid physical annihilation and cultural assimilation. This droves the Zionists to establish colonies in Argentina, Uganda, and mostly in Palestine in the late 19th century. Moreover, Spangler asserts the involvement of Great Power, Britain, and the Ottoman, also counted as an initial reason for the conflict. Furthermore, the rise of Palestine nationalism is a reaction of the Zionist movement. As Palestinian leaders found the Zionist settlers as a new phenomenon for the community unlike the indigenous Jews who had lived in Palestine before. Another struggle for the Palestinians was "to understand the continuous frustration Palestinians faced in connecting a cultural sense of identity to the apparatus of a state that could take its place within the world system of nation-states" (p. 97).

Most of the thinkers focusing on the roots of the issue involve cultural elements to identify the causes of the conflict. Though their analysis heavily covers beliefs, norms, and identity through historical traces, they do not refer to it as political culture analysis, showing that the role of political culture as a tool for analysis is insignificant. Moreover, they often indicate that the Israeli political culture elements triggered the conflict. As such, there has been very little research that elaborates on Palestine's political culture as a main factor of the conflict.

\subsection{Political culture as a tool of analysis}

The use of political-cultural theory as a tool to analyze the roots of the Israel-Palestine conflict has been rarely discussed by scholars and thinkers. However, Gamson (1981, p. 2) use political culture to examine the Arab-Israel conflict. He addresses that "idea elements in a culture do not exist in isolation but are grouped into more or less harmonious clusters or interpretive packages". He divides political culture elements into framing and reasoning devices. The devices that provide justifications or reasons for a general position are roots, consequences, and appeals to principle. In the roots part, means a "given package has a characteristic analysis of the causal dynamics underlying the strip of events" (ibid, p.4). It highlights the causality to which the root calls attention.

Street (1993) argues that political culture has been treated as an insignificant account in the political system. He asserts "political culture appears as secondary, 
enriching our understanding of political life, is not deemed essential to our comprehension of it" (p. 95). He reviews the debate of political culture from Marxism and functionalist thinkers, and Gabriel Almond and Sidney Verba's The Civic Culture. He emphasized the useful role of political culture: "a cultural theory must account for action more persuasively than do, say materialist or rational choice theories... it must demonstrate that political culture is an indispensable and decisive factor in such accounts" (p. 96). He suggests that political culture scholars need to expand their analysis into the implications of the explanatory power and role of political culture.

Pye (1991) agrees that the concept of culture in political science was slow to be used despite its relevance in many political issues. Culture tends to be put aside as it is perceived to lack explanatory power. However, Almond and Verba's work recentered political culture as an important account as it "answered several needs in political science and sensitized to the values of depth psychology" (p.490). While Street (1993) argues Almond's formulation of political culture still lacks an explanation of the role of culture in a political issue, Almond (1983) asserts that political culture theory attributes "some importance to political attitudes, beliefs, values, and emotion in the explanation of political, structural, and behavioral phenomena such as national cohesion, patterns of political cleavage, modes of dealing with political conflict, the extent and the character of participation in politics, and compliance with authority" (p.127).

Samuel Beer defined political culture as the relationship of people toward its polity and processes that give result in evaluating the whole system and a set of expressive symbols (Beer, (1982), cited in Almond and Verba, 1989, p.26). In a broad view, Beer's definition put similar explanation as Almond and Verba assert in their substantive contents. In contrast, Lucian Pye argues that political culture is more likely to focus on political development themes and it can help to understand developmental problems and processes (Pye, (1985), cited in Almond and Verba, 1989, p.27). Pye's definition suggests that political culture has certain roles to the extent it influences the values and culture embedded in the nations.

David J. Elkins and Richard E. B Simeon define political culture as assumptions about the political world which is a short-hand expression for a 'mindset' that functions to "limit attention to less than the full range of alternative behaviors, problems, and solutions which are logically possible" (Elkins and Simeon, 1979, p. 131). They assert that there is a significant distinction between political culture as descriptive and as an explanation. Political culture as a descriptive tool "orients to the group assumptions that largely unconscious about their political life" (Elkins and Simeon, 1979, p. 131). On the other hand, "political culture as an explanation emphasizes its conjunction with structural factors and it must always be comparative" (Elkins and Simeon, 1979, p. 131). Thus, they suggest if we "use political culture as 
an explanation, therefore we cannot rule out the roles of collective property of groups such as nations or classes" (Elkins and Simeon, 1979, p. 131). They also suggest examining institutional and structural features first before using political culture tools (Elkins and Simeon, 1979, p. 131).

According to those thinkers, we could see that political culture means how generally people in certain groups or nations behave toward its political system that becomes underpinning ideas of the existence of the nations. Thus, political culture could be one of the trigger factors that guide nations toward their visions, which sometimes would cause a conflict of interests with other nations. Furthermore, it highlights the roles of values and culture that could massively dominate people's behavior.

\title{
3. Political Culture Theory
}

There has been a long discussion among pundits about the definition of political culture and the explanatory power of political culture in the Israel-Palestine issue. The term 'political culture' was first coined in 1963 by Gabriel Almond and Sydney Verba in their book titled The Civic Culture. They defined political culture as "the specifically political orientations - attitudes toward the political system and its various parts, and attitudes toward the role of the self in the system" (Almond and Verba, 1963). They also assert that the political culture of a nation is "the particular distribution of patterns of orientation toward political objects among the members of the nation." (Almond and Verba, 1963). In 1989, they evolved the concept by arguing that:

\begin{abstract}
"Political culture is not a theory; it refers to a set of variables which may be used in the construction of theories. It imputes some explanatory power to the psychological or subjective dimension of politics, just as it implies that there are contextual and internal variables which may explain it" (Almond and Verba, 1989, p.26).
\end{abstract}

The aforementioned points show that political culture could be used as a tool to explain from a psychological point of view and behavior of a certain subject. Moreover, political culture is a compatible concept to examine why a certain political group tends to do something. Specifically, political culture may aid understanding of the reason for the clash between political interests of Israel and Palestine. Almond and Verba assert that there should be three broad accounts in analyzing the nation's political culture (Almond and Verba, 1989, p.27). The first account consists of system culture, process culture, and policy culture. The second account consist of varieties of orientations toward system, process, and policy objects. The third account comprises of the relatedness or systemic character of its components. 
Almond and Verba's political culture is suitable to explain the roots of the IsraelPalstine conflict since they provide detail and comprehensive explanatory tools in assessing nation's political culture. The three accounts of nation's orientation cover cognitive, affective, and evaluative aspect could demonstrating how the norms, beliefs, and system influence the attitudes of Israeli and Palestinian throughout the conflict (Street, 1997, p. 97). Thus, this paper will use Almond and Verba's three accounts of political culture nation in analyzing the causes of the Israel-Palestine conflict.

The first account is based on substantive content that consists of system culture, process culture, and policy culture. The system culture of a nation consists of the distributions of attitudes toward the national community, the regime, and the authorities (Almond and Verba, 1989, p.28). This also includes the sense of national identity, attitudes toward the legitimacy of the regime and its various institutions, and attitude toward the legitimacy and effectiveness of the incumbents of the various political roles (Almond and Verba, 1989, p.28). Thus, Israel's political culture in terms of its system culture includes the distribution of attitudes of Jewish people consist of Orthodox Jews and secular Jews against Zionist and the establishment of State of Israel, the Zionist movement, and Jewish general attitudes towards State of Israel authorities. From the Palestinian side, their political culture is based on their Arab national identity, Palestinian attitudes toward their nationalism during Ottoman Empire period, and their historical claiming of the land.

The process culture of a nation consists of attitudes toward the self in politics and attitudes toward other political actors (Almond and Verba, 1989, p.28). This could be observed in Zionist perception of other nation's presence in the land, specifically, on how Zionists treat and see Arab Palestinians in the land. In addition, Palestinian views of Jews who settle and occupied their land also one of the clashing interests that linger. The policy culture element would include preferences of people regarding the outputs and outcomes of politics, the ordering among different groups of people in the community of such political values as welfare, security, and liberty (Almond and Verba, 1989, p.28). This encompasses Jewish and Palestinian reactions to policies addressed to them, either from the external parties such as the United Nations, the British government, the Arab countries, and the respective authoritative parties from Israel and Palestine.

The second account is based on varieties of orientations toward system, process, and policy objects that cover cognitive, consisting of beliefs, information, and analysis; affective, consisting of feelings of attachment, aversion, or indifference; or evaluative, consisting of moral judgments of one kind or another (Almond and Verba, 1989, p.28). In this second account, it emphasizes people reactions toward things they put their faith and feelings into. This account refers to normative factors 
that drive behavior, which in this case refers to normative factors that underlie both Jewish and Palestinian interests in the conflict. From the Jewish side, the normative factors include Judaism, attachment feelings to the land, and moral judgment of the Arab Palestine people. On the Palestinian side, normative factors include to the relationship between their Islamic beliefs and the land. The belief, as Hamas asserts, is that the land is an endowment (Waqf) for the Palestinians, which explain their attachment to the land as a nation who have lived there for a long time.

Third, the relatedness or systemic character of its components. In the case of a certain population, these highlights attitudes toward foreign policy, domestic economic policy, and racial segregation may be parts of consistent ideology (Almond and Verba, 1989, p.28). This account consists of Jewish and Palestinian attitudes toward their authoritative system that has an impact both on foreign policy and domestic policy. It covers Israeli attitude toward a Zionist political system and Palestinian attitudes to the Palestinian Liberation Organization (PLO).

\section{Israel and Palestine Political Culture as the Causes of Conflict}

\subsection{Israeli Political Culture}

Israel's political culture cannot be separated from its identity as Jewish people who believe in the tenets of Judaism. It is important to note that not all Jewish people agree and support Zionist movement. The Orthodox Jews and Secular Jews argue that the establishment of State of Israel would give other nations an excuse to expel the Jewish population in their home nation to Palestine (Neal, 1995, p.10). To the Israeli political culture covers the Jews' attitudes toward their national community, the regime and authorities of the State of Israel, and tenets of Judaism as their ultimate life guides, the Zionist movement, their sense of national identity, and their attachment embedded in Jews myth toward the Promised Land. Over the centuries, Jews have been scattered from one another. Moreover, they are often treated indifferently in every country they lived in. The fear and insecurity they had experienced raised the need to gather under the nation-state to feel secure. As Spangler (2015) asserts, Jews encounter fear of assimilation, fear of physical annihilation, and social annihilation.

The Zionist movement led to the establishment of the State of Israel in 1948 (Ariely, 2018). The vision is to establish a national revival of the Jews in the promised land since they always are a scattered minority (Shlaim, 2000). As Avi Shlaim (2000) asserts that "Zionist solution was to end this anomalous existence and dependence on others, to return to Zion, and to attain majority status there and ultimately, political independence and statehood" (Shlaim, 2000, p.2). Though there were many places available as an option to establish a Jewish state, the search initiated by the 
Zionist movement, which emerged in the late 19th century, ended up in the Palestine area. This decision was based on their 'promised land' myth, which was tied to the existence of their historical religious sites, the Wailing Wall. The Zionists argue their claims are supported by the fact that Jewish people have maintained their ties to the homeland for 3700 years (Bard, 2002). Moreover, one of the claims is based on their biblical belief that the land was given to them as Abraham's descendants (Beinin and Hajjar, 2014, p.1). Thus, they have the right to own the land and to settle there.

The Zionist movement's mission to settle in the disputed land clashed with the belief of the Orthodox Jews. Even though the Orthodox Jews possess the same belief that Jews have an attachment to the land, they do not believe that a Jewish nation should transform into a nation-state system. They believe that the Torah would not approve of Zionist's behavior in establishing the Jews state. They argue that Zionists do not have the right to sovereignty in the Holy Land, thus, they do not represent and speak on behalf of the Jewish people. They assert that the Zionists "desecrate the sanctity of the land" (Lendman, 2014). Therefore, the Orthodox Jews tend to be sympathetic of the Palestinian view, as shown in their support Palestinian freedom and condemnation of the Israeli government's actions. The point that should be noted in this account is Judaism does not conflict with Islam. Fundamentally, their belief are not significant factor that causes conflict. Moreover, it is the Zionism movement with their interpretation of the Hebrew bible or known as Tanakh that conflicted the roots of conflict. As Ahmad Ashkar (2015) argues,"the Zionist movement used the biblical concept of the "Promised Land and the chosen people' to occupy Palestine, and to distribute its resources to the colonial Jews".

Another element of Israeli political culture is its purity of race belief. Many Jews believe they are God's chosen people and they do not see other nations equal to them, often to the point of antagonization. Rabbi Yosef described Arabs as 'snakes, son of snake' from religious scripture. (Ashkar, 2015). Moreover, there are many interpretations of Judaic scripture that describe other nations as "impure" and not human (Ibid, 2015, p. 1). Ashrawi argue that in order to maintain the purity of the State of Israel, the Palestinian treated as demographic treat (Ashrawi, 2002, p.100). She argues that Palestinian experience "systematic and racial dehumanization" that supported by the State of Israel policies (Ibid, 2002, p.99). This demonstrates that Israel's discrimination toward Palestine, both in social interaction and political participation, becomes one of the underlying reasons for conflict and influence Israel policies.

The last element of Israel's political culture is the Israeli attitude toward a political system that covers Zionist behavior in the political system. Theodor Herzl as the father of Zionism rebuilds the idea of the importance of the establishment of the State of Israel as the solution to the Jewish question over centuries. Herzl asserts 
that the "Jewish question is no more a social than a religious one.... It is a national question, which can only be solved by making it a political world-question to be discussed and settled by the civilized nations of the world in council" (Herzl, 2006, p.146). Herzl also suggests equality among different nations in the State of Israel, which is contrary to what they practice now (Dowty, 1998). From this framework's origin's, it suggests that Jews and other nations in the state would enjoy the same rights and obligations as citizens. However, these ideas did not work as ought to be. Palestine Arab was treated differently as they become second-class citizens under the oppression of Israeli authorities. They do not have the same rights as Jewish citizens. The state of Israel turns out to build discrimination institutions toward their citizens-Arab Palestine with Israel citizenship.

All in all, Israel's political culture that embedded in their national identity, sense of belonging to the promised land, and the vision of Zionism to have their state has resulted in clashing interests with Palestinians. The fundamental idea of the myth of the promised land encountering the reality that the land belonged to the Palestinian people since the Ottoman period. However, the Zionists strongly believe their narratives which drives them to do whatever they should do to take over the land. From this point, we could see that the power of myths and narratives could motivate the collective action of certain groups (West, 2003). Even though the truth of the myth might not be true, its influence in driving unimaginable people's actions.

\subsection{Palestinian Political Culture}

During the Ottoman Empire period, the Palestine land was under their authority, but the land did not register as any geopolitical entity. However, prior to 1914, as nationalism in Europe arise and the culture of evolution began, Palestinian Arab start to think and feel collectively (Harms, and Ferry, 2005, p.59). Alongside the arrival of Zionist settlers, the Palestinian leaders felt threaten and start to articulate their aspiration to be an independent nation-state to the Ottoman Empire. The efforts of Palestinian to seek for their national territory and independent state turned to had zero results. As a part of the Ottoman Empire, the lack of political will and the inability of the Ottoman empire to do something about the conflict has disappointed Palestinian (Neal, 1995, p.18). Palestinians was wandering and struggle alone makes them vulnerable during the occupation. Moreover, since the success of Zionism, in the Islamic Congress in December 1931, the Mufti of Jerusalem, Haj Amin alHusseini, sought to make it an Islamic as well as Arab issue (Mattar, 1988, p. 232).

Another element of Palestine political culture is Palestinian views toward Jewish people since the first wave of Zionist advancement came not for seeking asylum, but for the establishment of the State of Israel. Abu Zayyad argues that Jewish immigration was perceived as a threat to Palestinian existence and national aspiration for a state. Thus, Palestine has never been a land without people (Zayyad, 2008). 
The Palestinian attachment for the land is not only because of their habitat, but they have attachment because of religious reasons.

The policy culture element of Palestine's political culture was different during the pre-state and after the State of Israel was established. During the pre-state period, the response of Palestinian aligned with Arab interests is to defend the land and give the right of return for Palestinian. As they struggle in every reconciliation and policies such as in the Balfour Declaration 1919, British Mandate, Arab Revolt, the First Arab-Israel War in 1948, and the Second Arab-Israel War in 1967. After all the reconciliations, the Palestinian and Arabs position was that the "Jews people have no legitimate claims to their territory and the idea of establishing a Jewish state on any part of Palestinian land was unjust and unacceptable" (Galnoor, 2009, p.82). However, after the Arabs were defeated in the Arab-Israel War and the establishment of the State of Israel, Palestinians treated indifferently. As everything begins to go worse, Palestinian refugees are perceived as a threat to regional stability (Said, 1992, p.154). Said asserts that since 1967, the tension between Palestinian and Arabs has worsened after the declaration of the PLO) (Ibid).

Palestinian political culture cannot be separated Arab Nationalism and Islamic beliefs (Pappe, 2004, p. 79). In the early stage of the occupation, when Israelis encountered Palestinians, Arab countries defended Palestinian rights. Before the establishment of the State of Israel in 1948, Israel angered other Arab countries as they waged war in the first Arab-Israel War 1948 followed by the second Arab-Israel War in 1967. From this time until 1967, Palestinian Arab and Arabs countries shared the same interests. Moreover, as a nation that majority consist of Muslims, Palestine's political culture is heavily the land as a part of the Islamic empire and the land is a rightful endowment (waqf) for them (Schenker, 2008). Therefore, the land belonged to them as the collective property of Muslims, entailing a collective duty for all Muslims to defend their rights to the land. Principally, Jerusalem as the site of Night Journey of Muslim belief and the presence of Al-Aqsa mosque strengthen the sense of belonging to the land.

The last element of Palestine's political culture is the Palestinian attitudes toward PLO as their authoritative system at that time. The PLO was formed in May 1964 to alleviate the situation of Palestinian refugee under Yasser Arafat leadership and to fight for Palestine independence (Harms and Ferry, 2005, p. 108). While Arabs start to stay away from Palestinian issue, PLO presence gave hope for Palestinian people. The PLO through its guerilla warfare has enabled the refugee "to show enough resistance that Arab regimes left the refugees in their transitional camps, despite their perception as a destabilizing factor" (Pappe, 2004, p.283). However, for some fractions of Palestinian people in West Bank and Gaza area, PLO do not represent their interest on self-determination and independent issue (Gresh, 1988, p.29). This 
is due to the PLO did not emerge within people in the territory of the conflict, but through representative in the diaspora. Frisch argues that the right of independence of Palestinian must ultimately articulate and accommodate by the indigenous people not by their representative in diaspora (Frisch, 2012, p.242).

Overall, it is difficult to examine the role of Palestine's political culture in explaining the causes of the conflict as the conflict is mostly caused by the aggressive attitudes of Israel. As Walid Salem asserts that "the fact that Palestine was subjected to successive occupations throughout its history makes it easy to pin all the mistakes made by the Palestinians on external factors, where the Palestinians become the victim, free of responsibility and, thus, unable to change reality" (Salem, 2008). The friction and confrontation began when the Zionist movement aimed to build a Jewish State on Palestinian land and the arrival of the first waves of Jewish immigration to the land (Zayyad, 2008). However, through the examination of Palestine political culture, it shows that the lack of political will of Ottoman Empire and lack of authoritative system of Palestinian such as PLO, has made Palestinian in a most vulnerable position. Thus, the changing interests of the Arabs towards Palestinian issue in the middle of the conflict has weakened Palestinian position. The Palestinians are essentially fighting their national aspirations on their own (Spangler, 2015, p.136).

\subsection{Political Culture as a tool of analysis in explaining the causes of Israel and Palestine Conflict}

Elkins and Simeon (1979, p. 139) argue that using political culture could explain the differences between Israel and Palestine in the range of options considered by the population in deciding on a course of action. On the one hand, the Zionist decision to establish the State of Israel in 1948 might not be considered unless a majority of Jews did not have the same fundamental reasons to do so. On the other hand, Palestine's political cultures that has lack of legitimacy and inability of Arabs to advocate Palestinian aspirations give no other choice than struggling over the occupation. The second point is political culture analysis from both sides only could use after we separate their institutional and structural explanation (Elkins and Simeon, 1979, p. 140). If we see from Israel's political culture, they have significant roles in explaining the causes, since it is embedded deep in their construction of a belief system. However, political culture seems a minor variable in explaining the causes of Palestine's point of view. It is because, since the very beginning, Palestine lacks legitimacy and authority as a nation even though they are part of the Arab world. The third point is we could not only use political culture alone in examining and trying to understand the conflict. In a broader view, political culture complements other variables, because it could explain the bigger picture of this conflict (Elkins and Simeon, 1979, p. 140). Thus, we should look and collaborate with other instruments 
to help understand the political culture portion and roles in explaining the IsraelPalestine conflict.

\section{Conclusion}

Examining the roots and causes of the Israel-Palestine conflict has always been the center of attention. It has been 72 years since the establishment of the State of Israel, but no one has ever been satisfied with the efforts that scholars and thinkers have brought. People keep questioning the reason why Israel and Palestine's interests escalate into this never-ending conflict. Scholars have shown that the cultural element has always been an important aspect of understanding the roots of the conflict, despite political culture theory being rarely discussed. The political culture variable then becomes an interesting tool to understand both positions in the conflict. Through political culture analysis, the roots of the emergence of the Zionist movement that trigger Jews' gradual immigration to the Palestinian land can be explained. It also explains the very fundamental ideas of Judaism belief and Islam belief that it might be conflicting but can be compromised. Both beliefs bring the ideas of peace and equality, but different claims and narratives of the land make the issue look intolerable so that continuing the conflict and waging war is the only choice they have. Moreover, political culture also useful to explain Jewish and Palestinians perceived each other as "thieves" of their land, which further escalates the conflict. In conclusion, political culture is relevant to use as a tool in examining the causes of the Israel-Palestine conflict, but it is a minor variable to explain equally from both sides, especially for the Palestinian side.

\section{References}

\section{Books}

Almond, Gabriel and Sydney Verba. (1989). The Civic Culture Revisited. Sage Publications: California.

Ariely, Gal. (2018). Political Culture and Israeli Politics. The Oxford Handbook of Israeli Politics and Society. Oxford University Press.

Bove, Andrew. (2002). The Limits of Political Culture: An Introduction to G.W.F. Hegel's Notion of Bildung. In Questionable Returns, ed. A. Bove, Vienna: IWM Junior Visiting Fellows Conferences, Vol. 12

Dowty, Alan Dowty. (1998). The Jewish state: A century later. University of California Press: USA.

G, Mitchell Bard. (2002). Myths and facts: A guide to the Arab-Israel conflict. American Israeli Cooperative Enterprise: United States of America.

Gresh, Alain. (1988). The PLO: The Struggle Within: Towards an Independent Palestinian State. London: Zed Books

Harms, Gregory and Todd M. Ferry. (2005). The Palestine-Israel Conflict: A Basic Introduction, $4^{\text {th }}$ ed. Pluto Press: London 
Herzl, Theodor. (2006). The Jewish Question. In Stephen Eric Bronner (Eds), Twentieth Century Political Theory: A Reader (pp: 146-152). Britain: Routledge

Pappe, Ilan. (2004). A History of Modern Palestine: One Land, Two People. Cambridge: Cambridge University Press.

Said, Edward. (1992). The Question of Palestine. New York: Vintage Book.

Shlaim, Avi. (2002). The iron wall, Israel and the Arab World. W.W Norton and company.

Spangler, Eve. (2015). Understanding Israel/Palestine: Race, Nation, and Human Rights in the conflict. USA: Sense Publisher

\section{Journals}

Abu, Ziad Zayyad. (2008). Nakba and independence: two sides of the same coin. Palestine Israel Journal. Vol 15 No. 1 \& 2.

Almond, Gabriel. (1983). Communism and Political Culture Theory. Comparative Politics. Vol. 15, No.2

Ashkar, Ahmad Ashkar. (2015). On the Relationship between Zionism and Judaism. Palestine Israel Journal. Vol.20 No.4 \& Vol.21 No.1/ Religion and the Conflict.

Ashrawi, Hanan. (2002). Racism, Racial Discrimination, Xenophobia, and Related Intolerances. Islamic Studies, Vol.43, no.1, pp.99-104

Frisch, Hillel. (2012). The Demise of the PLO: Neither Diaspora nor Statehood. Political Science Quarterly Vol. 127, No. 2

Galnoor, Itzhak. (2009). The Zionist debates on partition (1919-1947). Israel Studies. Vol. 14, No. 2 (Summer, 2009), pp. 74-87

J, David Elkins and Richard E.B Simeon. (1979). A Cause in Search of its effect, or what does political culture explain? Comparative politics. vol.11 no.2, Jan.

Mattar, Philip. (1988). The Mufti of Jerusalem and the Politics of Palestine. Middle East Journal, Vol. 42, No. 2 (Spring, 1988), pp. 227-240

Oord, Lodewijk van. (2008). The Making of Primitive Palestine: Intellectual Origins of the Palestine-Israel Conflict. History and Anthropology. 19:3.

Pye, Lucian.W. (1991). Political Culture Revisited. Political Psychology. Vol. 12, No.3 Salem, Walid. (2008). Palestinian Contemporary Political Performance: A Bitter Harvest. Palestine-Israel Journal. Vol 15 No. 1 \& 2.

Schenker, Hiller. (2008). 1948 - Looking Backward, Looking Forward. Palestine Israel Journal. Vol 15 No. 1 \& 2.

Street, John. (1994). Political Culture - From Civic Culture to Mass Culture. British Journal of Political Science. Vol.24, no.1.

\section{$\underline{\text { Reports }}$}

L, Deborah West. (2003). 'Myth and Narrative in the Israeli-Palestinian Conflict', WFP Reports Number 34. 


\section{Conference Papers}

Gamson, A.William. (1981). The Political Culture of Arab-Israeli Conflict. Paper presented at Seventeenth North American Peace Science Conference. Peace Science Society (International). University Michigan. Philadelphia.

Neal, Lorena S. (1995). The Roots of the Israeli-Palestinian Conflict: 1882-1914. Honors Projects. Paper 27. Illinois Wesleyan University.

\section{Internet Sources}

$\begin{array}{llll}\text { Jewish Virtual (n.d). Library. } & \text { Retrieved from }\end{array}$ http://www.jewishvirtuallibrary.org/quot-the-jewish-state-quottheodor-herzl Lendman, Stephen. (2014). Jews against Zionism; an intro to their perspective. Retrieved from http://www.tikkun.org/nextgen/jews-against-zionism-an-intro totheir-perspective

Beinin, Joel Beinin and Lisa Hajjar. (2014). Palestine, Israel and the Arab-Israeli Conflict: A Primer, Middle East Research and Information Project. Retrieved From http://www.merip.org/palestineisrael primer/PalestineIsrael Primer MERIP.pdf 